\title{
Attitude of Health Workers to the Utilization of Immigrant Patients Health Services in Tamalanrea Health Center
}

\author{
R. Nurul Qalbi ${ }^{1}$, Indar Indar ${ }^{1 *}$, Rahmatiah Yunus ${ }^{2}$ \\ ${ }^{1}$ Department of Health Administration and Policy, Public Health of Faculty, Hasanuddin University, Makassar, Indonesia; \\ ${ }^{2}$ Department of Economics, Faculty of Economics and Business, Hasanuddin University, Makassar, Indonesia
}

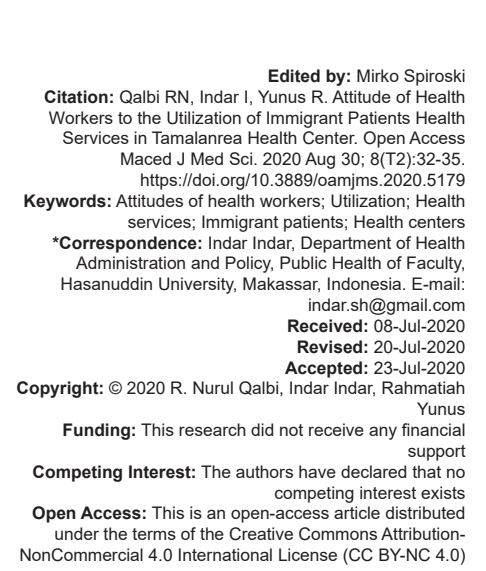

\section{Introduction}

Utilization of health services at the health center level has several factors that influence it, namely, consumer factors in the form of: Education, livelihoods, knowledge, and perceptions of patients; organizational factors such as availability of resources, affordability of service locations, and social access; and service provider factors including behavior of health workers [1].

Puskesmas is a first-level health service center that organizes quality health services. The service efforts that are organized are public health services, namely, promotive and preventive efforts in the community in the Puskesmas work area, basic medical services, namely, curative and rehabilitative efforts with individual and family approaches through treatment efforts aimed at curing diseases for certain conditions [2].

Indonesia is one of the largest archipelagic countries in the world and has a very unique and strategic geographical situation. The position of Indonesia makes Indonesia a place of connecting between the Asian continent and the Australian continent. Because of its location at the crossroads, Indonesia has become one of the favorite places for asylum seekers and international refugees as temporary shelters where Australia is the main destination country to seek protection or asylum. However, some illegal immigrants really want to stay to get a more decent living than in their home country [3].

In 2017, the President of the Republic of Indonesia signed a Presidential Regulation concerning the Handling of Refugees from Abroad. The presidential regulation contains the main definitions and regulates the detection, shelter, and protection of asylum seekers and refugees. Various provisions in the Presidential Regulation are expected to be implemented immediately. This will make the Government of Indonesia and UNHCR work more closely, including in the field of joint registration for asylum seekers [4].

Furthermore, the Indonesian government in the health sector has guaranteed the healthcare of immigrants by collaborating with the International Organization for Migration (IOM) with various hospitals and Puskesmas. This guarantee is out of the monthly allowance that is not given to immigrants every month. Thus, if an immigrant patient goes to a health center or hospital in collaboration with IOM, then all costs will be borne by IOM, but if the immigrant gets treatment outside of collaboration with IOM, then the immigrant 
must pay the fee with his pocket money. They have the right to choose where they want to get health services that make them feel satisfied with the services obtained [4].

The attitude of health workers is one of the factors that influence the utilization of health services so that it must be maintained and further improved so that patients feel comfortable and feel satisfaction in doing the treatment at the health center by getting a good attitude from the officers.

Research conducted by Singal et al. [5] in Kima Bajo Village shows that the attitude of health workers has a significant relationship in the utilization of health services. The existence of good and attentive treatment becomes a special attraction in providing services to patients. This fosters psychological influence and motivation for patients to utilize the health services provided [6]. Therefore, this study aimed to determine the attitude of health workers in the utilization of health services by immigrant patients in Tamalanrea Health Center.

The actions or ways in which officers perform services are things that greatly affect patients in the use of services. Actions or ways in which officers perform services are things that greatly affect patients associated with healing the disease. The existence of good and attentive treatment becomes a special attraction in providing services to patients. This provides psychological strength for patients and fosters a motivation to utilize the services provided [7].

The purpose of this study is to determine the relationship between the attitude of health workers in the utilization of health services for immigrant patients at Tamalanrea Health Center.

\section{Materials and Methods}

The study was conducted at the Tamalanrea Health Center in Makassar City, in August-September 2019. This research was conducted using a quantitative method with a case approach that aims to examine the attitudes of health workers toward immigrant patients in the utilization of health services at the Tamalanrea Health Center.

The population in this study was 154 people based on data in Tamalanrea Health Center in the past 6 months. In this study, the population was all immigrant patients seeking treatment at Tamalanrea Health Center more than once. The sampling technique in this study used purposive sampling in which this study took a sample based on certain considerations such as population characteristics or characteristics that were already known so that the number of samples was 59 people with inclusion criteria, namely, immigrant patients living in Puskesmas working areas Tamalanrea and have utilized health services for more than 1 visit.

Data collection is done by observation and questionnaire filling techniques. Data from the questionnaire filling were processed using the SPSS program.

Data analysis in quantitative research is carried out before entering the field, while in the field and after completion in the field. Data analysis was performed using the SPSS program.

\section{Results}

Table 1 shows the characteristics of the immigrant patients who were respondents in this study. Most of the respondents aged 26-36 years (44.1\%), male sex $(91.5 \%)$, the most recent education was the high school/equivalent category (44.1\%), from the country with the most, namely, from Afghanistan $(89.8 \%)$ with the most length of stay in Makassar for 5 years $(28.8 \%)$.

Table 1: Characteristics of respondents in the Tamalanrea Health Center, 2019

\begin{tabular}{lll}
\hline Characteristics & $\mathrm{n}$ & $\%$ \\
\hline Age (year) & & \\
15-25 & 20 & 33.9 \\
$26-36$ & 26 & 44.1 \\
$37-47$ & 11 & 18.6 \\
$48-58$ & 2 & 3.4 \\
Gender & & \\
Male & 54 & 91.5 \\
Female & 5 & 8.5 \\
Latest Education & & \\
Not graduated elementary school & 4 & 6.8 \\
Elementary school & 7 & 11.9 \\
Junior high school & 17 & 28.8 \\
Senior high school & 26 & 44.1 \\
University & 5 & 8.5 \\
Country of origin & & \\
Afghanistan & 53 & 89.8 \\
Ethiopia & 1 & 1.7 \\
Myanmar & 2 & 3.4 \\
Sudan & 3 & 5.1 \\
Long stay in Makassar (years) & & \\
1 & 4 & 6.8 \\
2 & 10 & 16.9 \\
3 & 5 & 8.5 \\
4 & 7 & 11.9 \\
5 & 17 & 28.8 \\
6 & 11 & 8.6 \\
7 & 5 & 8.5 \\
\hline
\end{tabular}

Table 2 shows that of the 39 respondents who stated the attitude of positive health workers as many as 25 people who had used health services, and as many as 14 people had not used health services whereas of the 20 respondents who stated the attitude of negative health workers as many as 20 people in the category had used health services and as many as 0 people who had not used health services at Tamalanrea Health Center.

Table 2: Attitudes of health workers with utilization of health services in Tamalanrea Health Center, 2019

\begin{tabular}{|c|c|c|c|c|c|c|c|}
\hline \multirow{2}{*}{$\begin{array}{l}\text { The attitude of } \\
\text { health workers }\end{array}$} & \multicolumn{2}{|c|}{ Utilize } & \multicolumn{2}{|c|}{ Not utilize } & \multicolumn{2}{|c|}{ Total } & \multirow[t]{2}{*}{$\mathrm{p}$} \\
\hline & $\mathrm{n}$ & $\%$ & $\mathrm{n}$ & $\%$ & $\mathrm{n}$ & $\%$ & \\
\hline Positive & 25 & 64.1 & 14 & 35.9 & 39 & 100.0 & 0,002 \\
\hline Negative & 20 & 100.0 & 0 & 0.0 & 20 & 100.0 & \\
\hline
\end{tabular}


Statistical test results in Table 2 obtained the value of $p=0.002$ because the value of $p<\alpha=0.000$ $<0.05$ then $\mathrm{Ho}$ is rejected, this means that there is a relationship between the variables of the attitude of health workers with the utilization of health services in Tamalanrea Health Center.

\section{Discussion}

Based on the results of the study, a statistically significant correlation was obtained in the utilization of immigrant patients' health services at Tamalanrea Health Center.

The actions or methods of personnel performing services are those which greatly affect the patient in the use of services. Actions or ways of health workers in performing services are things that greatly affect patients related to the healing of the disease. The existence of good and attentive treatment becomes a special attraction in providing services to patients. This provides psychological strength for patients and fosters a motivation to utilize the services provided [7].

The attitude in the service of health workers is defined as the reaction or response of health workers/ nurses in performing health services accompanied by a tendency to take action on objects (patients) according to the needs of patients.

Attitudes can be demonstrated through three components of attitude, namely, cognitive, affective, and conative. In reality, patients as consumers are often sidelined or overlooked by service providers. From the patient's perspective, many complaints are submitted, and the patient's rights are not given enough attention regarding slow service, lack of friendliness, and lack of support facilities. Attitude is a mental and nervous state of readiness that is regulated through experience, which gives a dynamic or directed influence on individual responses to all objects and situations related to them [7].

The results of this study are in line with the results of research conducted by Wulandari and Saptaputra [8], which shows the results of the Chisquare statistical analysis, the value of $p=0.008$ means that $\mathrm{Ho}$ is rejected $\mathrm{Ha}$ accepted. This indicates that there is a relationship between the attitude of the officers and the utilization of health services by the Langara community. Research conducted by Singal et al. [5] with the results of the test of the relationship between attitude and the use of Puskesmas by the Kima Bajo village community, the Chi-square statistical test results showed a value of $p<0.05$ so it can be concluded that there is a relationship between attitude and utilization Puskesmas. Research conducted in the Kima Bajo village can be seen that attitudes associated with the use of health centers are because the community feels compatible with the services at the health center so that people choose to use the health center.

The results of this study are also in line with the results of research conducted by Rumengan et al. [7] which shows the results of the Chi-square test analysis obtained a probability value (Significance) of $0.000(p<0.05)$ with an error rate $(\alpha) 0.05$, which means that there is a significant relationship between respondents' perceptions of staff actions and the use of health services at the Puskesmas. Judging from the value of the odds ratio, it shows that respondents with a perception of the actions of the officer are 8.5 times more likely to utilize health services at the Puskesmas.

According to Rumengan et al. [7], community perceptions of Puskesmas services need to be improved by providing continuous special training for health workers regarding illnesses or health problems in the community so that the alacrity and speed in overcoming these health problems are getting better. The limited ability and skills of health workers in the Community Health Center in dealing with diseases affect people's trust in treatment; for this reason, it is necessary to increase the ability and skills in health services to improve the performance of health workers.

Communication with patients about a service process that is being provided will give rise to positive perception and support themselves to be able to accept the actions given. The service that is responsive and supported by a friendly attitude and sincerity in responding to the problems faced is a matter of support and also determines success in health services and also affects the healing of patients.

Limited English proficiency does not only affect migrants' access to health services but also the quality of health services provided. In a Canadian study comparing the utilization of health services among refugees, immigrants, and the general population, refugees were found to use more services than immigrants but less than the general population. However, it is not known whether this difference is due to the characteristics of migrants, the host country, or the health care system. Future studies are needed in the US that focuses more specifically on Arab migrants [9].

The existence of good and attentive treatment becomes a special attraction in providing services to patients. This fosters psychological influence and motivation for patients to utilize the health services provided [10], [11], [12]

\section{Conclusion}

It was concluded that the attitude of health workers toward the utilization of health services for immigrant patients in general has a statistically 
significant relationship. It is expected that the attitude of health workers can be maintained and further improved so that the utilization of health services by immigrant patients increases.

\section{Recommendation}

Suggestions for Tamalanrea Health Center to further enhance good attitudes to patients to create trust and satisfaction in utilizing health services in the Tamalanrea Health Center. It is hoped that further research can add new variables such as staff language proficiency or length of stay in Makassar in influencing the utilization of health services for immigrant patients at the Tamalanrea Health Center.

\section{References}

1. Abdullah A, Sjattar EL, Kadir AR. Faktor penyebab terjadinya penurunan jumlah kunjungan peserta program pengelolaan penyakit kronis (prolanis) di puskesmas minasa upa kota makassar. J IImiah Kesehatan Diagn. 2017;11(4):382-7. https:// doi.org/10.7454/jki.v22i3.880

2. Mertisanfara Y. Pelayanan Kesehatan Dasar Bagi Masyarakat Miskin Di Puskesmas Terakreditasi (Studi Tentang Prosedur dan Kualitas Pelayanan Kesehatan Dasar di Puskesmas Rawat Inap Kedaton) (Skripsi). Bandar Lampung: Universitas Lampung; 2018. https://doi.org/10.26630/jk.v7i1.122

3. Maulana I, Afrizal A. Upaya pemerintah indonesia dalam menangani masalah imigran ilegal yang menuju australia tahun 2012-2015. J Online Mahasiswa Fakultas IImu Sosial IImu Polit Univ Riau. 2016;3(1):1-15.
4. Nst ED. Peranan international organization for migration (IOM) dalam menangani permasalahan refugees (pengungsi) rohingya di Indonesia. J Power Int Relat. 2018;2(1):70-81.

5. Singal HI, Kandou GD, Rumayar AA. Hubungan antara pengetahuan, sikap dan pendapatan dengan pemanfaatan puskesmas oleh masyarakat desa kima bajo kecamatan wori. Kesmas. 2019;7(5):1-8.

6. Irawan B, Ainy A. Analisis faktor-faktor yang berhubungan dengan pemanfaatan pelayanan kesehatan pada peserta jaminan kesehatan nasional di wilayah kerja puskesmas payakabung, Kabupaten Ogan Ilir. J Ilmu Kesehatan Masyarakat. 2018;9(3):189-97. https://doi.org/10.26553/ jikm.2018.9.3.189-197

7. Rumengan DS, Umboh J, Kandou G. Faktor-faktor yang berhubungan dengan pemanfaatan pelayanan kesehatan pada peserta BPJS kesehatan di Puskesmas Paniki Bawah Kecamatan Mapanget Kota Manado. Jikmu. 2015;5(2):88-100. https://doi.org/10.26553/jikm.2018.9.3.189-197

8. Wulandari C, Saptaputra S. Faktor yang berhubungan dengan pemanfaatan pelayanan kesehatan di UPTD puskesmas langara kecamatan wawonii barat kabupaten konawe kepulauan tahun 2016. J IImiah Mahasiswa Kesehatan Masyarakat. 2017;1(3):19. https://doi.org/10.26553/jikm.2018.9.3.189-197

9. Elsouhag D, Arnetz B, Jamil H, Lumley MA, Broadbridge CL, Arnetz J. Factors associated with healthcare utilization among Arab immigrants and Iraqi refugees. J Immigr Minor Health. 2015;17(5):1305-12.https://doi.org/10.1007/s10903-014-0119-3 PMid:25331684

10. Napitupulu IK, Carolina B. A characteristics of predisposition and ability of family resources in family decision for utilizing of health services in puskesmas kelurahan pasir kaliki 2017. J Kesehatan Prima. 2018;12(1):47-53. https://doi.org/10.32807/ jkp.v12i1.92

11. Rachmawati D, Amir M. Faktor yang berhubungan dengan pemanfaatan pelayanan kesehatan di puskesmas tamalanrea kota makassar. UNHAS. 2014;5(4):79-104. https://doi. org/10.36060/jfs.v5i1.40

12. Masriadi, Azis R, Sumantri E, Mallongi A. Effectiveness of non pharmacologic therapy through surveillance approach to blood pressure degradation in primary hypertension patients, Indonesia. Indian J Public Health Res Dev. 2018;9(4):294. https://doi.org/10.5958/0976-5506.2018.00292.9 